\title{
Rappresentare significa Connettere. Il caso del Rock Show Design
}

\author{
Maurizio Unali
}

\section{Abstract}

Rappresentare è un'arte e una scienza che si alimenta di 'connessioni', variamente declinate nella storia rispetto alle idee e alle conoscenze tecno-culturali del tempo in cui si attua tale modus operandi. In questo senso, le opere che hanno scandito la storia della rappresentazione possono essere considerate dei "modelli semantici"; metafora dei tempi, esito di ibridazioni culturali e riciclaggi estetici coscienti dei riferimenti concettuali, dei metodi e delle tecniche di configurazione.

In questo ampio ambito di studio sul valore "dialogico" del processo rappresentativo, il caso del Rock Show Design sembra essere fra i più interessanti della contemporaneità: il secolo scorso è stato il periodo della storia più ricco di rappresentazioni!

Lo stato dell'arte relativo agli studi sulla rappresentazione scenica rock riguarda soprattutto la sfera musicale del fenomeno, talune performance di successo o il lavoro svolto da alcuni noti set designers. Lo studio presentato è l'ultimo esito di una lunga ricerca (tuttora in corso), elaborata dallo scrivente, sulla storia della rappresentazione scenica rock, di cui si tratteggia una densa sintesi evolutiva, illustrando anche la metodologia adottata. Si tratta di una complessa storia, qui presentata in forma di "vertigine della lista", suddivisa in una timeline tripartita, fondata soprattutto sulle connessioni delle rappresentazioni effimere rock con l'architettura, il design, l'arte e la cultura musicale pop.

Appare il disegno di una mappa concettuale per stimolare il dibattito, approfondire la ricerca e innescare applicazioni nella didattica.

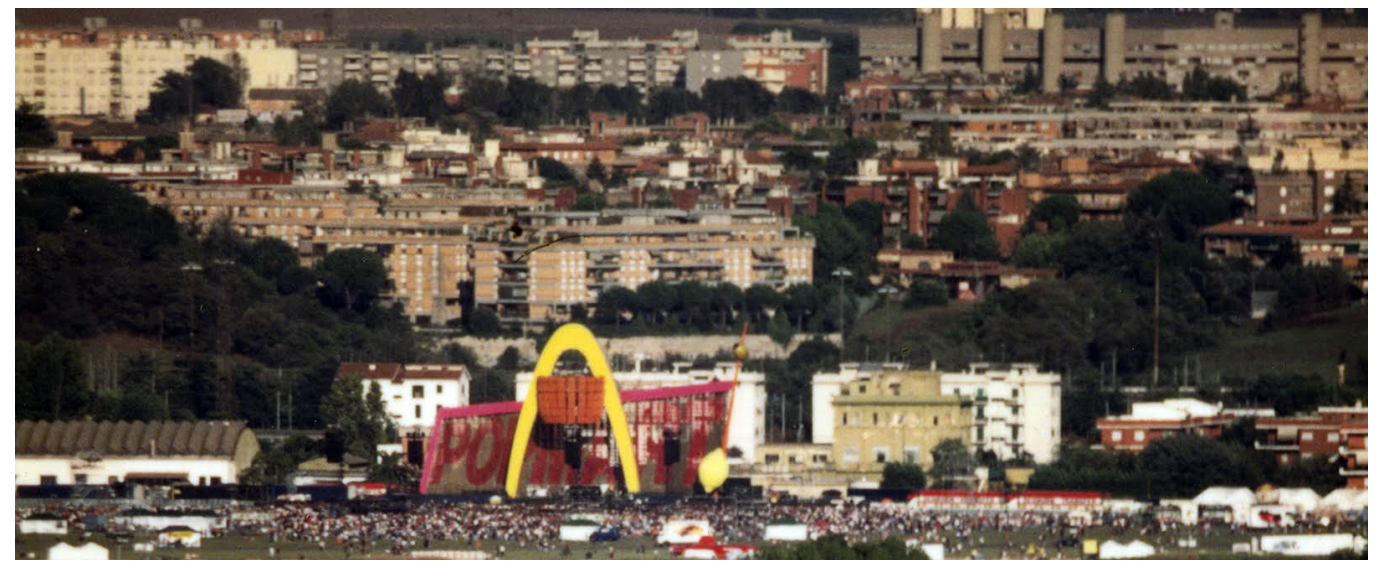




\section{Introduzione}

L'affascinante storia delle idee che ci accingiamo a tratteggiare esplora l'evoluzione del progetto dello spazio scenico per l'evento live della musica "Pop-Rock" - qui denominato sinteticamente Rock Show Design - come esito delle relazioni tra l'architettura, il design, l'arte e la cultura Pop.

È un composito processo progettuale alimentato da ibridazioni culturali che concorrono a generare ambienti immersivi da "abitare per una notte" nell'effimero spazio-tempo multisensoriale dell'evento; relazioni che concorrono a disegnare rappresentazioni dal forte impatto emozionale; esperienze radicali, socializzanti (di spirito situazionista), da vivere collettivamente in real time nella popolare e spettacolare dimensione pubblica della performance, in cui abita da sempre l'Homo Ludens.

Si tratta, inoltre, di un progetto di rappresentazione che potenzialmente consente di espandere le singole discipline coinvolte, sintetizzando, ampliando e (re) inventando arti, deformando e avvicinando strategie espressive per ottenere il massimo effetto espressivo; una interessante mixité che utilizza diverse tecniche e linguaggi innescando riciclaggi estetici e "connessioni" (appunto).

In questo scenario dell'entertainment l'architettura, soprattutto in quanto storica disciplina che si occupa della rappresentazione e conformazione dello spazio, è metaforicamente "madre" del progetto scenico; laboratorio privilegiato di sperimentazione delle diverse declinazioni della cultura Pop e di una "estetica di massa".

$\grave{E}$ un progetto che ripropone, quindi, il tema dello sconfinamento disciplinare, pratica vitale per rinnovare il valore della ricerca, il senso ludico della scoperta, la creatività generata dal confronto con l'Altro. Fruttuoso procedere che consente di esplorare i territori di confine dell'architettura; quei luoghi di frangia in cui l'architettura (come per l'arte e per la musica), entrando in contatto con altre forme d'espressione, attraverso il confronto e il dialogo fra ambiti creativi diversi, innesca processi di contaminazione e genera nuove rappresentazioni spazio-temporali.

Lo studio presentato è l'ultimo esito di una lunga ricerca (tuttora in corso) elaborata dallo scrivente [I] sulla storia della rappresentazione scenica rock, di cui si tratteggia una densa sintesi evolutiva, illustrando anche la metodologia adottata. Si tratta di una complessa storia (che attraversa circa sette decenni), qui presentata (per motivi editoriali) in forma di "vertigine della lista" [2], suddivisa in una timeline tripartita, fondata soprattutto sulle connessioni delle rappresentazioni effimere rock con l'architettura, il design, l'arte e la cultura musicale pop.

Appare il disegno di una mappa (work in progress) per stimolare il dibattito, approfondire la ricerca e innescare ricadute nella didattica.

\section{Per una storia (... in tre parti) della rappresentazione scenica rock: dagli esordi al nuovo millennio}

Dalla seconda metà del secolo scorso, il progetto di allestimento scenico della musica "PopRock" ha innovato la storia dello spettacolo (e non solo), ampliando, sperimentando e inventando spazi multisensoriali che hanno conformato un nuovo modello di rappresentazione live. Coinvolgenti ambienti immersivi, fra il reale e il virtuale, ma anche fra l'ideale e l'utopico, in grado di connettere culturalmente, prima di internet e dei social, quasi tutto il globo.

Sono opere pluridisciplinari a tutti variamente note che oggi sembrano appartenere a una cultura condivisa; empatici spazi effimeri, emozionanti performance, esperienze socializzanti che innescano azioni "situazioniste", mediatiche, soprattutto nella POPolare dimensione del fenomeno e nel contesto di una creatività di massa fondata - n. b. solo nei casi migliori - su un progetto transculturale all'insegna del cosmopolitismo e dell'universalismo, in grado di rappresentare sogni e speranze di più generazioni. Ad iniziare da quella Beat. 


\section{Parte Prima. \\ Antefatti, avanguardie, origini e riferimenti del rock show design: dalla metà degli anni ' 50 alla fine dei ' 60}

Le radici della performance rock risalgono al secondo dopoguerra - "il punto d'inizio" - e, in particolare, sono da ricercare nella cultura degli Stati Uniti d'America degli anni Cinquanta dove, intorno alla metà del decennio, nasce il Rock'n'roll e, con esso, inizia progressivamente a configurarsi un nuovo genere di spettacoli live caratterizzati da specifici allestimenti scenici che, attraversando una serie d'intense ibridazioni progettuali, dagli anni '60 arrivano fino alle tecno-culture di fine millennio.

Questa parte della ricerca è introdotta da alcune questioni teoriche che aiutano a contestualizzare i progetti scenici nel periodo in esame. Fra i principali temi trattati ricordiamo: rappresentare le culture giovanili; nuova critica per nuova estetica nella società dello spettacolo; architettura, arte e rock come mass media; tutti hanno abitato lo spettacolo Pop; riferimenti '50-'60, "l'internazionale dell'utopia", architetture radicali in un'epoca di grandi trasformazioni; strutture tridimensionali, gonfiabili e strutture pneumatiche.

Dopo aver studiato alcuni colti antefatti progettuali - da Wagner a Gropius, sinestesie e "Musica per lo Spazio" - la ricerca ha esplorato gli esordi del rock show approfondendo le principali idee sceniche elaborate nell'arco dei suoi due decenni fondativi.

Negli anni '50 rileviamo, quindi, la nascita del Rock'n'roll Show, studiata in primis approfondendo le performance degli artisti del periodo - da Elvis "the Pelvis" a Chuck Berry -, analizzando le prime esperienze dei Festival musicali e discretizzando le forme intrinseche della rappresentazione scenica, come, ad esempio, l'estetica dei corpi e delle maschere live, costantemente reiterata in tutta l'evoluzione storica dello spettacolo rock.

Sempre alla ricerca di connessioni con altre progettualità, e in relazione ai rapporti tra la pop art, la musica, l'architettura e il design, abbiamo approfondito alcuni significativi eventi, come, ad esempio, la mostra This is Tomorrow (Londra, 1956): progetto culturale che genera, a più livelli, importanti spunti creativi, come la nascita della pop art (chiave interpretativa di molti rock set) e il produttivo approccio interdisciplinare svolto dall'Indipendent Group (collettivo composto da artisti, architetti, scrittori e critici).

Alla fine del decennio i tempi sono ormai maturi per nuovi modelli di rappresentazione. Sarà soprattutto l'architettura a ideare innovativi spazi effimeri, dal multisensoriale Padiglione Philips con il Poème électronique di Le Corbusier, Xenakis eVarèse per l'Expo di Bruxelles '58, ai radicali progetti Pop per l'Homo Ludens, da New Babylon '59 di Constant al Fun Palace '6l di Cedric Price (solo per citarne alcuni).

Arrivati negli anni '60 tutto sembra trovare naturali sentieri evolutivi all'insegna dell'innovazione e della sperimentazione.

Per le eccezionali personalità creative, per le nuove progettualità multimediali, per il popolare successo degli eventi e per le virtuose connessioni tra le arti, la rappresentazione del rock negli anni '60 è una straordinaria galassia espressiva, origine e, ancora oggi, costante fonte di riferimenti dello show design (e non solo).

Sono gli anni del primo concerto di massa in uno stadio - The Beatles, Shea Stadium, New York'65 - e della svolta multimediale della seconda metà del decennio.

In particolare, l'esplosione della rappresentazione psichedelica innesca un originale laboratorio creativo che si configura come un modello meta-progettuale all'insegna dei Mixed-Media (dagli Happening americani al British Underground, dagli Acid Tests alla Swinging London).

La storia dei Light Show nella rappresentazione rock testimonia poi una prolifera declinazione dell'arte psichedelica, nel tempo oggetto di continui riferimenti e aggiornamenti tecno-culturali. Le origini rock di questa forma di rappresentazione - prodotta attraverso l'uso di speciali diapositive contenenti sostanze liquide colorate sensibili al calore del proiettore - sono da ricercare nelle prime sperimentazioni allestite nella metà degli anni Sessanta in America e in Inghilterra.

Nella scena USA ricordiamo: Jordan Belson e i Vortex Concerts (1957-1960); The Joshua Light Show (tra San Francisco e New York); le rappresentazioni Absolutely Free di Frank 
Zappa a New York nel '67; The exploding plastic inevitable show (New York '66), progettato da Andy Warhol con i Velvet Underground (giochi di luci e colori, danze, monologhi, immagini e, sullo sfondo, alcuni schermi dove sono proiettati i film di Warhol), un nuovo modello di rappresentazione live che ha innovato la storia dello spettacolo, determinando una rivoluzionaria soglia visivo-sensoriale che ha avuto anche il merito di ibridare cultura Pop, movimenti d'avanguardia e media.

Nella scena inglese ricordiamo: il gruppo artistico composto da Mark Boyle e Joan Hills; i primi spettacoli underground dei giovani Pink Floyd nella Swinging London; I 4-HourTechnicolor Dream (Londra '67), una originale "maratona" ( 4 ore) di mixed-media, tra spettacoli di musica, arte, teatro, poesia, danza, luci, colori e immagini, messinscena da musicisti, artisti, performer e acrobati.

II decennio si chiude poi con un evento storico per gli spettacoli di massa, il Festival di Woodstock '69, ispirazione della Instant City degli Archigram (ma non solo).

\section{Parte Seconda.}

Architetture sceniche itineranti: dagli anni ' 70 alla "Grande Festa" di fine millennio. Spettacolarizzazione dell'evento live, successo globale, eccesso e declino?

Superati gli anni delle rivoluzionarie performance dei gruppi d'avanguardia del "visual rock", dalla seconda metà degli anni '70 fino alla fine del secolo, la rappresentazione scenica live si è fortemente evoluta. Con il moltiplicarsi delle occasioni progettuali, sono state realizzate architetture sceniche itineranti molto complesse e dall'articolata logistica; produzioni dai costi e dai ricavi esorbitanti che hanno coinvolto numerose creatività e competenze.

Nasce così la cosiddetta industria dello spettacolo rock, che ha contribuito ad ampliare discipline e definire nuove professionalità, provenienti da diversi percorsi formativi.

Un progetto multidisciplinare realizzato da un'équipe di lavoro che vede all'opera, oltre ai musicisti, diverse sensibilità professionali: architetti, designer, scenografi, ingegneri, artisti, light designer, coreografi, performer, tecnici del suono, grafici, registi ecc.

Sono questi alcuni fra i principali argomenti trattati nella seconda parte della ricerca qui sintetizzata, che affronta l'arco temporale più prolifero del rock set.

Fra le infinite implicazioni teoriche che emergono in questi caleidoscopici tre decenni, oltre al già citato tema aperto dall'evoluzione dell'industria dello spettacolo rock - con tutto quello che ciò ha significato in termini di creazione di nuove professionalità, scuole e condizionamento degli obiettivi -, il secondo approfondimento è rivolto ai processi di riciclaggio estetico elaborati, con il relativo tentativo di evidenziarne i principali riferimenti concettuali e visivi innescati. Primo fra tutti l'irruzione della rivoluzionaria informatica nella sfera artistica e, in particolare, le pervasive "cyberculture Pop".

Entrando invece nella dimensione performativa delle opere realizzate, proviamo a ricordarne alcune suddividendole per decenni.

Negli anni '70 - trasgressiva stagione creativa che si confronta con la nuova "avanguardia di massa", con le mutate condizioni metropolitane e con le molteplici declinazioni della musica rock - emergono i raccolti spazi immersivi indoor del Rock Theatre espressi dalla musica Progressive - nebbiose e oniriche atmosfere di immagini e luci, corpi, maschere e costumi, trovate sceniche ecc. -, come quelli messi in scena dai Genesis, i maestri di questo genere di allestimenti (Trespass '70, Selling England By The Pound '73, The Lamb Lies Down On Broadway '74-'75) o come gli spazi onirici degli Yes (da Topographic Oceans '72 a Crab Nebula '76) disegnati dai fratelli Dean, caratterizzati dall'uso innovativo di luci laser e dal palco circolare "In the Round".

Rimanendo nella dimensione indoor, ma in tutt'altre atmosfere, ricordiamo poi gli spazi della Disco Music (iconicamente rappresentati nel 1977 dal film Saturday Night Fever) e i provocatori show del Punk (dai Sex Pistols ai Clash).

Fra i primi palcoscenici itineranti della storia del rock set segnaliamo le scenografie "Pop-Orwelliane" dello show Animals "77 dei Pink Floyd, progettate dallo studio Fisher \& Park. 
Dagli anni '80, fortemente caratterizzati da parole chiave come "megaconcerti, look, cyber e caos ipertecnologico", registriamo una diffusa qualità tra i tanti allestimenti scenici realizzati, diviso tra innovazione, tradizione e bieco mercato, sotto un'incombente, vera o presunta, ciclica sensazione di "crisi" ereditata dal decennio precedente.

II decennio si apre con The Wall Show Tour '80-'8I, fra i "monumenti” storici del rock show design.

Sono anche gli anni degli esordi del prolifero "laboratorio U2" (con War Tour '82-'83, The Joshua Tree '87 e LoveTown Tour '89-'90) della Performance Art musicale con i raffinati progetti di Laurie Anderson (United States '8I -'82, Home of the Brain '84) e delle ampie scenografie urbane degli show di Jean-Michel Jarre (da Cities in concert'86 a Paris-LaDéfense '90).

Chiudono il decennio due storici progetti: Rolling Stones, Steel Wheels, Tour '89-'90; Pink Floyd, Momentary Lapse of Reason, Tour '88-'89, con lo spettacolare allestimento del palcoscenico galleggiante sulle acque diVenezia.

Ricordiamo inoltre: Stevie Wonder, Hotter than July '80; Ultravox, Quartet '82; Wham, Whamamerica '85; Roger Waters, Pros \& Cons of Hitchhiking '85, Radio K.A.O.S. '87; George Michael, Faith '88.

Gli anni '90 si aprono con un altro storico spettacolo-evento con unica data, Roger Waters, The Wall in Berlin, organizzato per celebrare la caduta del Muro di Berlino.

Nell'ultimo decennio del secolo il rock show raggiunge il più alto livello progettuale, soprattutto in termini di spettacolarizzazione dell'evento, diffusione e qualità complessiva delle imponenti macchine sceniche d'interfaccia realizzate.

Fra gli show supertecnologici del periodo, emblematiche testimonianze della consacrazione e dissacrazione del fenomeno, ma anche, forse, del suo epilogo, ricordiamo:

- i Rolling Stones con Urban Jungle, Tour '90, Gig@ByteCity, ovvero Voodoo Lounge, Tour '94'95 e Bridges to Babylon, Tour '97-'99;

- gli U2 con '90: ZooTV - Outsider Broadcast, Tour '92-'93 e PopMart, Tour '97-'98;

- lo spazio-immagine di Anton Corbijn per i Depeche Mode, Devotional Tour '93;

- il teatro musicale di Peter Gabriel e Robert Lepage: Secret World, Tour '93-'94;

- i Pink Floyd con The Division Bell,Tour '94;

- Phil Collins con Dancing into the Light,Tour '97-'98;

- il palcoscenico progettato da Zaha Hadid per il World Tour'99-'20 dei Pet Shop Boys.

Infine, gli allestimenti per la "Grande Festa" [3] di fine millennio sembrano chiudere metaforicamente l'evoluzione del più sperimentale rock show: dalle piramidi di Giza con Michel Jarre ad OVO di Peter Gabriel e Mark Fischer nel Millennium Dome di Richard Rogers a Londra.

Progettualità che hanno profondamente ampliato l'idea storica di rappresentazione, contribuendo a rinnovare l'antica pulsione umana verso le poetiche dell'effimero, espanse nei più storicizzati territori dell'architettura e dell'arte.

Infine, tornando sul tema delle nuove professionalità innescate dall'industria dello spettacolo rock, si evidenzia il ruolo svolto dallo show designer (o set designer), una competenza che richiede grandi capacità nel saper tenere la regia di fenomeni complessi di natura multidisciplinare.

In questo contesto, il ruolo svolto dall'architetto londinese Mark Fisher (1947/20 I3) - creatore dei più significati allestimenti scenici pop-rock del secolo - è emblematico, rappresentando un positivo punto di riferimento per la storia dello spettacolo live, guadagnandosi sul campo una credibilità e una fama internazionale che ne ha dichiarato l'indiscusso primato nel settore dello show design.

Uno fra gli elementi chiave di questo successo è rintracciabile, innanzitutto, nella formazione del progettista, che ha studiato all'Architectural Association di Londra nella seconda metà degli anni '60 - scuola di fondamentale importanza per capire le relazioni tra l'architettura e le arti in un clima di scambio interdisciplinare - in un periodo tra i più creativi dell'università londinese, dove gli Archigram in quel periodo costituivano parte del corpo docente. 


\section{Parte Terza. \\ Effimero spettacolare d'inizio millennio. Dove stiamo andando?}

Dopo le spettacolari performance messe in scene in circa settant'anni di rock show, dove stiamo andando? Dopo le potenti architetture sceniche allestite - che hanno superato i 100 metri di larghezza (Roger Waters, The Wall Live 20 I3) e un'altezza di circa 50 (U2 360 Tour 2009) - quali estetiche, quali nuove soglie multisensoriali si stanno prefigurando?

Fra i tour dei soliti big e quelli delle nuove proposte, fra inaugurazioni ed eventi vari (television awards, celebrazioni ecc.), le rappresentazioni sceniche prodotte in questi ultimi due decenni sono infinite, proponendo interessanti soluzioni tipologiche, toccando vari record (incassi, pubblico, dimensioni, effetti speciali ecc.), esprimendo un alto livello tecnico e professionale, agevolato dall'esperienza storica raggiunta dal fenomeno e dall'enorme evoluzione tecno-culturale.

È una storia che merita specifici approfondimenti tematici e ricerche finalizzate all'elaborazione di una sorta di atlante sui tanti progetti realizzati: lo spazio scenico "in the round" di Growing Up Tour 2002-2003 di Peter Gabriel (con la "Zorb Ball", la sfera trasparente al cui interno Gabriel salta sul palco e, idealmente, sopra le teste degli spettatori); le architetture mobili dei Rolling Stones (Forty Licks 2002, A Bigger Bang 2005, 50th Anniversary Tour 20 I2; 14 On Fire 2014, No Filter Tour 2017-2018); le performance di Antony and the Johnsons, Swanlights, 20 I2; l'ultimo Coachella Valley Music and Arts Festival in California ecc.

Ma questa evoluzione tecnologica e professionale del rock show design non è sempre seguita da un altrettanto progresso creativo delle idee messe in scena, spesso poco sperimentali e forse troppo appiattite sui vecchi stilemi tratti dai classici successi del lungo repertorio dello spettacolo rock.

Per non parlare, poi, di alcuni fastosi spettacoli live in cui la pochezza della proposta artistico-musicale stona palesemente con le mega scenografie commissionate dalle produzioni, evidenziando evidenti dissonanze estetico-comunicative. Attenzione, quindi, a ingenui entusiasmi e semplicistiche analisi.

Nell'attuale era post-digitale si evidenzia così, anche da questo punto di vista, l'importanza di ampliare gli studi specifici su quell'insieme di esperienze multidisciplinari che appartengono alla sfera creativa della rappresentazione live; empatiche poetiche dell'effimero che sembrano appartenere ad un trasversale sentire connettivo dei nostri tempi, dove rappresentare significa sempre di più 'connettere'!

\section{Note}

[I] Per meglio comprendere il lavoro qui presentato va detto che esso si inserisce in un lungo percorso di ricerca sulle poetiche dell'effimero in architettura e, in particolare, sul tema della rappresentazione scenica pop-rock, curato dallo scrivente, i cui esiti sono sintetizzati nelle pubblicazioni riportate in bibliografia.

[2] Riferimento concettuale liberamente tratto dal titolo e dai contenuti del libro di Umberto Eco (2009). Vertigine della lista. Milano: Bompiani.

[3] Riferimento concettuale liberamente tratto dai contenuti del libro: Vittorio Lanternari (2004). La grande festa. Vita rituale e sistemi di produzione nelle società tradizionali. Bari: ed. Dedalo (I ed. 1959).

\section{Riferimenti bibliografici}

Broackes Victoria, Landreth Strong, Anna (a cura di). (2017). Pink Floyd. Their mortal remains. Milano: Skira.

Brougher Kerry et al. (a cura di). (2005). Visual Music. Synaesthesia in Art and Music Since 1900. London:Thames \& Hudson.

Derossi Pietro (1993). Tecnologia Rock. In Lotus international, 79, pp. 89- 101.

Holding Eric (2000). Mark Fisher. Staged architecture. In Architectural Monographs No 52, West Sussex: Wiley-Academy.

Lyall Sutherland (1992). Rock Sets. The Astonishing Art of Rock Concert Design. The works of Fisher Park. London: Thames and Hudson. 
Unali Maurizio (2013). Memoria, misura e tutela del patrimonio architettonico effimero. In Conte Antonio, Filippa Monica (a cura di). Patrimoni e siti Unesco. Memoria, misura e armonia. Roma: Gangemi, pp. 967-974.

Unali Maurizio (20I2). II design della luce e del colore nella performance rock. Verso una storia. In Rossi Maurizio, Siniscalco Andrea (a cura di). Colore e Colorimetria. Contributi Multidisciplinari. Atti della VIII Conferenza del Colore. Bologna: Maggioli.

Unali Maurizio (20 I0). Architettura effimera. In XXI Secolo. Gli spazi e le arti. Opera diretta da T. Gregory. Roma: Istituto della Enciclopedia Italiana fondata da Giovanni Treccani, pp. 345-354: < www.treccani.it/enciclopedia/architettura-effimera_(XXI_ Secolo)/>.

Unali Maurizio (2007). Superluoghi per una notte. In Agnoletto Matteo, Delpiano Alessandro, Guerzoni Marco (a cura di). La civiltà dei Superluoghi. Notizie dalla metropoli quotidiana. Bologna: Damiani, pp. I73- 174.

Unali Maurizio (2007). Rappresentare l'evento. Show design, tra architettura e cultura rock. Macchine sceniche itineranti. In Mezzetti Carlo (a cura di). Intersezioni diSegni. Roma: Kappa, pp. 296-3।4.

Unali Maurizio (2006). Effimero. In Purini Franco, Marzot Nicola, Sacchi Livio (a cura di). La Città Nuova. Italia-y-2026. Invito a VEMA. Padiglione Italiano alla 10. Mostra Internazionale di Architettura. Voce contenuta in D.A.I. (Dizionario Architettonico Italiano). Bologna: Compositori, pp. 358-359.

Autore

Maurizio Unali, Università degli Studi “G. d'Annunzio" di Chieti-Pescara, maurizio.unali@unich.it

Per citare questo capitolo: Unali Maurizio (2020). Rappresentare significa Connettere. Il caso del Rock Show Design/To represent means to connect. The case of Rock Show Design. In Arena A., Arena M., Brandolino R.G., Colistra D., Ginex G., Mediati D., Nucifora S., Raffa P. (2020). Connettere. Un disegno per annodare e tessere. Atti del $42^{\circ}$ Convegno Internazionale dei Docenti delle Discipline della Rappresentazione/ Connecting. Drawing for weaving relationships. Proceedings of the 42th International Conference of Representation Disciplines Teachers. Milano: FrancoAngeli, pp. 2855-2868. 


\title{
To Represent Means to Connect. The Case of Rock Show Design
}

\author{
Maurizio Unali
}

\section{Abstract}

To represent is an art and a science that feeds on "connections", variously declined in history with respect to the techno-cultural ideas and knowledge of the time in which this modus operandi is implemented. In this sense, the works that have marked the history of representation can be considered "semantic models"; a metaphor for the times, the result of cultural hybridizations and aesthetic recycling conscious of conceptual references, methods and configuration techniques.

In this wide field of study on the "dialogic" value of the representative process, the case of Rock Show Design seems to be one of the most interesting of the contemporary time: the last century was the richest period of representations!

The state of the art concerning the studies on the rock scenic representation mainly concerns the musical sphere of the phenomenon, some successful performances or the work done by some wellknown set designers.

The study presented is the latest outcome of a long research (still in progress), elaborated by the writer, on the history of rock stage performance, of which a dense evolutionary synthesis is outlined, also illustrates the methodology adopted. It is a complex story, presented here in the form of a "vertigo of the list", divided into a tripartite timeline, based above all on the connections of ephemeral rock performances with architecture, design, art and pop music culture.

A conceptual map appears to stimulate debate, deepen research and trigger applications in didactics.

\section{Keywords}

history of representation; ephemeral architecture; rock show design; live multimedia event; representing mass culture.

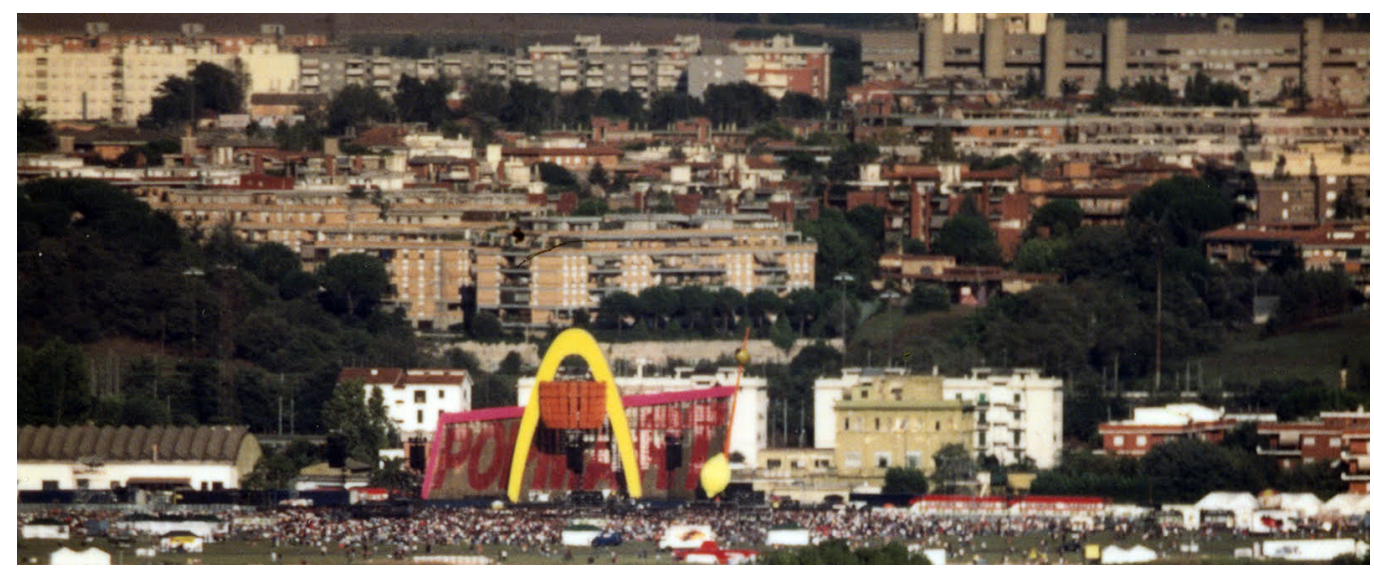




\section{Introduction}

The fascinating story of the ideas we are about to sketch explores the evolution of the design of the stage space for the live music event "Pop-Rock" - here synthetically called Rock Show Design - as a result of the relationship between architecture, design, art and Pop culture.

It is a composite design process fed by cultural hybridizations that contribute to generate immersive environments to "live for a night" in the ephemeral multisensory space-time of the event; relationships that contribute to draw representations with a strong emotional impact; radical, socializing (with a Situationist spirit), experiences to be lived collectively in real time in the popular and spectacular public dimension of the performance, where Homo Ludens has always been living.

It is also a project of representation that potentially allows the single disciplines involved to expand, synthesizing, expanding and (re)inventing arts, deforming and approaching expressive strategies to obtain the maximum expressive effect; an interesting mixité that uses different techniques and languages triggering aesthetic recycling and "connections" (precisely). In this entertainment scenario, architecture, especially as a historical discipline that deals with the representation and conformation of space, is metaphorically "mother" of the scenic design; a privileged laboratory of experimentation of the different declinations of Pop culture and "mass aesthetics".

It is a project that proposes, therefore, the theme of disciplinary trespassing, a vital practice to renew the value of research, the playful sense of discovery, the creativity generated by comparison with the Other. It is a fruitful process that allows us to explore the borderline territories of architecture; those fringe places where architecture (as for art and music), coming into contact with other forms of expression, through comparison and dialogue between different creative fields, triggers processes of contamination and generates new space-time representations.

The presented study is the latest outcome of a long research (still in progress) elaborated by the writer [I] on the history of rock stage performance, of which a dense evolutionary synthesis is outlined, also illustrating the methodology adopted. It is a complex story (spanning about seven decades), presented here (for editorial reasons) in the form of a "vertigo of the list" [2], divided into a tripartite timeline, based mainly on the connections of ephemeral rock performances with architecture, design, art and pop music culture.

The drawing of a map (work in progress) appears to stimulate debate, deepen research and trigger consequences in teaching.

\section{For a story (... in three parts) of the rock stage performance: from the beginning to the new millennium}

Since the second half of the last century, the scenic design of the "Pop-Rock" music has innovated the history of the show (and not only), expanding, experimenting and inventing multisensory spaces that have shaped a new model of live performance. Involving immersive environments, between the real and the virtual, but also between the ideal and the utopian, able to connect culturally, before the internet and social networks, almost the entire globe. They are multi-disciplinary works that today seem to belong to a shared culture; empathic ephemeral spaces, exciting performances, socializing experiences that trigger "situationist" actions, mediated, especially in the POPular dimension of the phenomenon and in the context of a mass creativity founded - n. b. only in the best cases - on a transcultural project under the banner of cosmopolitanism and universalism, able to represent dreams and hopes of several generations. Starting with the Beat culture. 


\section{Part One. \\ Background, avant-garde, origins and references of rock show design: from the mid-'50s to the late '60s.}

The roots of rock performance date back to after World War II - "the starting point" - and, in particular, are to be found in the culture of the United States of America in the 1950s where, around the middle of the decade, Rock'n'roll was born and, with it, a new genre of live shows gradually began to take shape, characterized by specific stage productions that, through a series of intense design hybridizations, span from the 1960s to the techno-cultures of the end of the millennium.

This part of the research is introduced by some theoretical questions that help to contextualize the scenic projects in the period under consideration. Among the main themes dealt with are: representing youth cultures; new critique for new aesthetics in the society of entertainment; architecture, art and rock as mass media; all have inhabited the Pop show; "50s and '60s references, "the international of utopia", radical architectures in an era of great transformations; three-dimensional, inflatable and pneumatic structures.

After studying some sophisticated design backgrounds - from Wagner to Gropius, synesthesia and "Music for Space" - the research explored the beginnings of rock show by studying in depth the main scenic ideas developed during its two founding decades.

In the '50s we note, therefore, the birth of the Rock'n'roll Show, studied in depth the performances of the artists of the period - from Elvis "the Pelvis" to Chuck Berry -, analyzing the first experiences of music festivals and discretizing the intrinsic forms of stage performance, such as, for example, the aesthetics of bodies and live masks, constantly repeated throughout the historical evolution of the rock show.

Always looking for connections with other projects, and in relation to the relationship between pop art, music, architecture and design, we have deepened some significant events, such as, for example, the exhibition This is Tomorrow (London, 1956): a cultural project that generates, on several levels, important creative ideas, such as the birth of pop art (interpretative key of many rock sets) and the productive interdisciplinary approach carried out by the Independent Group (collective composed of artists, architects, writers and critics).

At the end of the decade the time is ripe for new models of representation. It will be architecture, above all, that will create innovative ephemeral spaces, from the multisensory Philips Pavilion with Poème électronique by Le Corbusier, Xenakis and Varèse for the Brussels Expo '58, to the radical Pop projects for Homo Ludens, from Constant's New Babylon '59 to Cedric Price's Fun Palace '6I (just to name a few).

Arrived in the 60s everything seems to find natural evolutionary paths in the name of innovation and experimentation.

For the exceptional creative personalities, for the new multimedia projects, for the popular success of the events and for the virtuous connections between the arts, the representation of rock in the '60s is an extraordinary expressive galaxy, origin and, still today, constant source of references of show design (and not only).

These are the years of the first mass concert in a stadium - The Beatles, Shea Stadium, New York '65 - and the multimedia turning point of the second half of the decade.

In particular, the explosion of psychedelic representation triggers an original creative workshop that is configured as a meta-project model under the banner of Mixed-Media (from American Happening to British Underground, from Acid Tests to Swinging London).

The history of Light Shows in rock representation testifies to a prolific declination of psychedelic art, over time the object of continuous references and techno-cultural updates. The rock origins of this form of representation - produced through the use of special slides containing coloured liquid substances sensitive to the heat of the projector - are to be found in the first experiments set up in the mid-1960s in America and England.

In the US scene we remember: Jordan Belson and the Vortex Concerts (1957-1960); The Joshua Light Show (between San Francisco and New York); Frank Zappa's Absolutely Free performances in New York in '67; The exploding plastic inevitable show (New York '66), designed by Andy Warhol with the Velvet Underground (games of lights and colours, dances, mono- 
logues, images and, in the background, some screens where Warhol's films are projected), a new model of live representation that has innovated the history of the show, determining a revolutionary visual-sensorial threshold that has also had the merit of hybridizing Pop culture, avant-garde movements and media.

In the English scene, we remember: the artistic group composed by Mark Boyle and Joan Hills; the first underground shows of the young Pink Floyd in Swinging London; I 4-Hour Technicolor Dream (London '67), an original "marathon" (I 4 hours) of mixed-media, between shows of music, art, theatre, poetry, dance, lights, colours and images, staged by musicians, artists, performers and acrobats.

The decade then closes with a historic event for mass shows, the Woodstock Festival '69, inspired by Archigram's Instant City (but not only).

\section{Part Two.}

Travelling scenic architecture: from the 1970s to the "Great Festival" at the end of the millennium. Live event spectacularization, global success, excess and decline?

After the years of the revolutionary performances of the avant-garde "visual rock" bands, from the second half of the 70s until the end of the century, the live stage performance has strongly evolved. With the multiplication of design opportunities, very complex and logistically articulated itinerant scenic architectures have been realized; productions with exorbitant costs and revenues that have involved numerous creativity and skills.

This is how the so-called rock show business was born, which has helped to expand disciplines and define new professions, coming from different training courses.

A multidisciplinary project carried out by a work team that sees at work, in addition to musicians, different professional sensibilities: architects, designers, set designers, engineers, artists, light designers, choreographers, performers, sound engineers, graphic designers, directors etc.

These are some of the main topics dealt with in the second part of the research summarized here, which deals with the most proliferous time span of the rock set.

Among the infinite theoretical implications that emerge in these kaleidoscopic three decades, in addition to the aforementioned theme opened by the evolution of the rock show business - with all that this has meant in terms of the creation of new professions, schools and setting of objectives -, the second in-depth study is addressed to the processes of aesthetic recycling elaborated, with the relative attempt to highlight the main conceptual and visual references triggered. First of all, the irruption of the revolutionary information technology in the artistic sphere and, in particular, the pervasive "Pop Cybercultures".

Entering instead into the performative dimension of the realized works, we try to remember some of them by dividing in decades.

In the "70s - a transgressive creative season that confronts the new "mass avant-garde", with the changed metropolitan conditions and the multiple declinations of rock music - the indoor immersive spaces of the RockTheatre emerge, expressed by Progressive Music - foggy and dreamlike atmospheres of images and lights, bodies, masks and costumes, scenic finds, etc. like those staged by Genesis, the masters of this kind of staging (Trespass '70, Selling England By The Pound '73, The Lamb Lies Down On Broadway '74-'75) or like the dreamlike spaces of Yes (from Topographic Oceans '72 to Crab Nebula '76) designed by the Dean brothers, characterized by the innovative use of laser lights and the circular stage "In the Round".

Remaining in the indoor dimension, but in all different atmospheres, we remember the spaces of Disco Music (iconically represented in 1977 by the movie Saturday Night Fever) and the provocative Punk shows (from Sex Pistols to Clash).

Among the first touring stages in the history of rock set history we point out the "Pop-Orwellian" set design of Pink Floyd's Animals '77 show, designed by Fisher \& Park studio.

Since the " 80 s, strongly characterized by key words such as "megaconcerts, look, cyber and hyper-technological chaos", we have been recording a widespread quality among the many stage productions made, divided between innovation, tradition and the biased market, under 
a looming, real or presumed, cyclical feeling of "crisis" inherited from the previous decade. Since the " 80 s, strongly characterized by key words such as "megaconcerts, look, cyber and hyper-technological chaos", we have been recording a widespread quality among the many stage productions made, divided between innovation, tradition and the grim market, under a looming, real or presumed, cyclical feeling of "crisis" inherited from the previous decade. The decade opens with The Wall Show Tour '80-' 8 I, one of the historical "monuments" of rock show design.

These are also the years of the beginnings of the proliferous "U2 laboratory" (with WarTour '82-'83, The Joshua Tree '87 and LoveTown Tour '89-'90), of the musical Performance Art with the elegant projects of Laurie Anderson (United States '81-'82, Home of the Brain '84) and of the wide urban scenographies of Jean-Michel Jarre's shows (from Cities in Concert ' 86 to Paris-LaDéfense '90).

Two historical projects close the decade: Rolling Stones, Stee/ Wheels, Tour '89-'90; Pink Floyd, Momentary Lapse of Reason, Tour '88-'89, with the spectacular setting of the floating stage on the waters of Venice.

We also remember: Stevie Wonder, Hotter than July '80; Ultravox, Quartet '82; Wham, Whamamerica '85; Roger Waters, Pros \& Cons of Hitchhiking '85, Radio K.A.O.S. '87; George Michael, Faith '88.

The 90s opens with another historical show with only one date, Roger Waters, The Wall in Berlin, organized to celebrate the fall of the Berlin Wall.

In the last decade of the century, the rock show reached the highest level of design, especially in terms of spectacularity of the event, diffusion and overall quality of the impressive created stage interface machines.

Among the super-technological shows of the period, emblematic evidence of the consecration and desecration of the phenomenon, but also, perhaps, of its epilogue, we remember: - The Rolling Stones with Urban Jungle, Tour '90, Gig@ByteCity, or Voodoo Lounge,Tour '94-'95 and Bridges to Babylon, Tour '97-'99;

- the U2 with '90: ZooTV - Outsider Broadcast, Tour '92-'93 and PopMart,Tour '97-'98;

- The image-space by Anton Corbijn for the Depeche Mode, Devotional Tour '93;

- The musical theater of Peter Gabriel and Robert Lepage: Secret World,Tour '93-'94;

- the Pink Floyd with The Division Bell, Tour '94;

- Phil Collins with Dancing into the Light,Tour '97-'98;

- the stage designed by Zaha Hadid for the Pet Shop Boys'World Tour'99-'20.

Finally, the preparations for the "Great Party" [3] at the end of the millennium seem to metaphorically close the evolution of the most experimental rock show: from the pyramids of Giza with Michel Jarre to OVO by Peter Gabriel and Mark Fischer in Richard Rogers' Millennium Dome in London.

Designs that have profoundly expanded the historical idea of representation, contributing to renew the ancient human impulse towards the poetics of the ephemeral, expanded in the most historicized territories of architecture and art.

Finally, returning to the theme of the new professional skills triggered by the rock show business, we highlight the role played by the show designer (or set designer), a skill that requires great expertise in being able to direct complex phenomena of multidisciplinary nature.

In this context, the role played by the London architect Mark Fisher (1947/20 I 3) - creator of the most significant pop-rock stage sets of the century - is emblematic, representing a positive point of reference for the history of live entertainment, earning in the field a credibility and international fame that has declared its undisputed leadership in the field of show design.

One of the key elements of this success is to be found, first of all, in the training of the designer, who studied at the Architectural Association in London in the second half of the 1960s - a school of fundamental importance for understanding the relationship between architecture and the arts in a climate of interdisciplinary exchange - in one of the most creative periods of the University of London, where Archigram were part of the teaching staff at the time. 


\section{Part Three. \\ Spectacular ephemeral of the beginning of the millennium. Where are we going?}

After the spectacular performances staged in about seventy years of rock shows, where are we going? After the powerful scenic architectures set up - which have exceeded 100 meters in width (Roger Waters, The Wall Live 20I3) and a height of about 50 (U2 $360^{\circ}$ Tour 2009) - what aesthetics, what new multisensory thresholds are we setting?

Between the tours of the usual big names and those of the new proposals, between openings and various events (television awards, celebrations, etc.), the stage performances produced in the last two decades are endless, proposing interesting typological solutions, touching various records (receipts, audience, size, special effects etc.), expressing a high technical and professional level, facilitated by the historical experience reached by the phenomenon and the enormous techno-cultural evolution.

It is a story that deserves specific thematic in-depth analysis and research aimed at drawing up a sort of atlas on the many projects carried out: the scenic space "in the round" of Growing Up Tour 2002-2003 by Peter Gabriel (with the "Zorb Ball", the transparent sphere inside which Gabriel jumps on stage and, ideally, above the heads of the spectators); the mobile architecture of the Rolling Stones (Forty Licks 2002, A Bigger Bang 2005, 50th Anniversary Tour 2012; I 4 On Fire 2014, No Filter Tour 2017-18); the performances of Antony and the Johnsons, Swanlights, 20 I2; the latest Coachella Valley Music and Arts Festival in California, etc. But this technological and professional evolution of rock show design is not always followed by as much creative progress as the ideas staged, often not very experimental and perhaps too flattened on the old styles taken from the classic hits of the long repertoire of rock show design.

Not to mention, then, some sumptuous live shows in which the smallness of the artistic-musical proposal clearly clashes with the mega sets commissioned by the productions, highlighting obvious aesthetic-communicative dissonances. Attention, then, to naïve enthusiasm and simplistic analysis.

In today's post-digital era, it is thus highlighted, also from this point of view, the importance of expanding specific studies on that set of multidisciplinary experiences that belong to the creative sphere of live representation; empathic poetics of the ephemeral that seem to belong to a transversal connective feeling of our times, where representation means more and more "to connect"!

\section{Notes}

[I] In order to better understand the work presented here it must be said that it is part of a long research on the poetics of the ephemeral in architecture and, in particular, on the theme of pop-rock scenic representation, edited by the writer, whose results are summarized in the publications reported in the bibliography.

[2] Conceptual reference freely taken from the title and contents of Umberto Eco's book: Umberto Eco (2009). Vertigine della lista. Milano: Bompiani.

[3] Conceptual reference freely taken from the contents of the book of Vittorio Lanternar: Vittorio Lanternari (2004). La grande festa. Vita rituale e sistemi di produzione nelle società tradizionali. Bari: ed. Dedalo (I ed. I 959).

\section{References}

Broackes Victoria, Landreth Strong, Anna (a cura di). (2017). Pink Floyd. Their mortal remains. Milano: Skira.

Brougher Kerry et al. (a cura di). (2005). Visual Music. Synaesthesia in Art and Music Since 1900. London:Thames \& Hudson.

Derossi Pietro (1993). Tecnologia Rock. In Lotus international, 79, pp. 89- 101.

Holding Eric (2000). Mark Fisher. Staged architecture. In Architectural Monographs No 52, West Sussex: Wiley-Academy.

Lyall Sutherland (1992). Rock Sets. The Astonishing Art of Rock Concert Design. The works of Fisher Park. London: Thames and Hudson. 
Unali Maurizio (2013). Memoria, misura e tutela del patrimonio architettonico effimero. In Conte Antonio, Filippa Monica (a cura di). Patrimoni e siti Unesco. Memoria, misura e armonia. Roma: Gangemi, pp. 967-974.

Unali Maurizio (20I2). II design della luce e del colore nella performance rock. Verso una storia. In Rossi Maurizio, Siniscalco Andrea (a cura di). Colore e Colorimetria. Contributi Multidisciplinari. Atti della VIII Conferenza del Colore. Bologna: Maggioli.

Unali Maurizio (20 I0). Architettura effimera. In XXI Secolo. Gli spazi e le arti. Opera diretta da T. Gregory. Roma: Istituto della Enciclopedia Italiana fondata da Giovanni Treccani, pp. 345-354: < www.treccani.it/enciclopedia/architettura-effimera_(XXI_ Secolo)/>.

Unali Maurizio (2007). Superluoghi per una notte. In Agnoletto Matteo, Delpiano Alessandro, Guerzoni Marco (a cura di). La civiltà dei Superluoghi. Notizie dalla metropoli quotidiana. Bologna: Damiani, pp. I73- 174.

Unali Maurizio (2007). Rappresentare l'evento. Show design, tra architettura e cultura rock. Macchine sceniche itineranti. In Mezzetti Carlo (a cura di). Intersezioni diSegni. Roma: Kappa, pp. 296-3।4.

Unali Maurizio (2006). Effimero. In Purini Franco, Marzot Nicola, Sacchi Livio (a cura di). La Città Nuova. Italia-y-2026. Invito a VEMA. Padiglione Italiano alla 10. Mostra Internazionale di Architettura. Voce contenuta in D.A.I. (Dizionario Architettonico Italiano). Bologna: Compositori, pp. 358-359.

\section{Author}

Maurizio Unali, Università degli Studi “G. d'Annunzio” di Chieti-Pescara, maurizio.unali@unich.it

To cite this chapter. Unali Maurizio (2020). Rappresentare significa Connettere. Il caso del Rock Show Design/To represent means to connect. The case of Rock Show Design. In Arena A., Arena M., Brandolino R.G., Colistra D., Ginex G., Mediati D., Nucifora S., Raffa P. (2020). Connettere. Un disegno per annodare e tessere. Atti del $42^{\circ}$ Convegno Internazionale dei Docenti delle Discipline della Rappresentazione/ Connecting. Drawing for weaving relationships. Proceedings of the 42th International Conference of Representation Disciplines Teachers. Milano: FrancoAngeli, pp. 2855-2868. 